general meeting, a lecture was delivered by Sir Henry Dale on "Biological Standardization". Sir Henry outlined the history of the establishment of standards for the biological assay of preparations of physiologically active products such as antitoxins, hormones, vitamins, etc. Attempts to set up units in terms of physiological effects under particular experimental conditions ('rat units', 'mouse units', etc.) have led to wide discrepancies and great confusion, owing largely to the difficulty of reproducing the conditions under which the proposed units were first determined. Following the pioneer work of Paul Ehrlich, the systematic establishment of international 'units of activity' based on stable standard preparations of the active substances was begun under the auspices of the Health Organisation of the League of Nations in 1921, and a number of these standards have been prepared at the State Serum Institute, Copenhagen. Standards for a still larger number of products have more recently been prepared in Great Britain at the National Institute for Medical Research, Hampstead. A general account was given on these developments and some particulars of the standard proparations now available.

\section{A Bird-watcher's Experiences}

IN a lecture to the University of London Animal Welfare Society, at Bedford College on March 8, Mr. Eric Hardy, of the British Empire Naturalists' Association, spoke of his experiences as a birdwatcher in various parts of Great Britain. $\mathrm{He}$ mentioned how a day-by-day census and survey of the sparrow population of the Liverpool Cathedral Birds' Sanctuary, in the heart of city slums eight miles from open country, failed to prove any great migration out of the city to country harvest fields as is often supposed, although many other migrants, chiefly warblers, passing over the city, use the sanctuary as a resting-place. This famous little sanctuary is to be reconstructed and re-equipped this year by the Merseyside Branch of the British Empire Naturalists' Association, which will be its custodian in the future. Mr. Hardy gave his experiences of the increasing numbers of buzzards and ravens in Wales, how swifts and tawny owls aro among the birds adapting themselves to life in growing towns, even in the industrial north. The annual May shooting of baby rooks in the nest is a cruel sport, he said, and oven apart from that question, field-studies show that unless rooks are in abnormal numbers, they do more good than harm on the land. The habit of taking regular censuses of bird numbers in various areas has added considerably to our knowledge of bird movements and migrations, especially with shore birds.

\section{Archæological Excavations in Cornwall}

Relics obtained from excavations on a late Bronze and Iron Age site in the Great Gear Field at Carwarthen, St. Just-in-Roseland, Cornwall, are now on exhibition in the museum of the Royal Cornwall Polytechnic Society at Falmouth. These excavations have been carried out during the past year under the direction of Mr. S. A. Opie of Redruth. The site, it would appear from an account of the excavations in the Royal Cornwall Gazette and County News of February 22, was occupied from 1000 B.c. onward. In the earlier phases of its occupation, it is the first to be identified in Cornwall as dating from the important Late Bronze Age period, to which belong the earliest classical references to the Western tin trade. The site is thus of unusual interest and importance; while in view of the small area as yet explored, it is the richest and most productive of the period of its later occupation as yet examined in Cornwall. A fair amount of bronze age pottery, some with cordon and finger-tip impressions, has been recovered; but as yet no traces of structural remains of the early period have been found. A small circular fortification belongs to a later occupation, being of a usual iron age type. Of this, the position of the circular ditch has been established at six points where it is from six to ten feet deep. Stone revetments of the inner face of the ditch have been found at five points. The ramparts, much damaged by ploughing, afford evidence of several periods of construction. At the best preserved section, there are three successive stone revetmonts, and clear evidence of an interior wall walk. The iron age pottery is mostly late, being attributed to the first century A.D. or at oldest to the first century B.c. None of the fine decorated pottery of the second century B.c., such as has been found at Glastonbury or Castle Dore, has appeared. The site was extensively occupied in Roman times down to the fourth century. Native pottery betrays Roman influence, while two pieces of Samian of the second century A.D. and two of Now Forest wares of the fourth century A.D. have been unearthed. Coins, numerous fragments of iron implements, perforated slate disks and a waisted stone hammer have also been found. The excavations are to be continued.

\section{Electric Generators at Boulder Dam}

DURING 1938, Engineering published a series of articles dealing with the remarkable work being carried out at Boulder Dam, Arizona. This project has a three-fold purpose-flood control, storage of water for irrigation and domostic and industrial use, and the generation of electric power. There are two power-houses, the Nevada wing and the Arizona wing, and the series of articles reforred to is brought to a close by a description of the electrical equipment being installed in these. 'I'he two articles on this subject are by Mr. L. N. McClollan, and were published in Engineering for February 10 and 24. There will ultimately be eight large units of $82,500 \mathrm{k.v} . \mathrm{a}$. in the Nevada wing and seven similar units and two units of 40,000 k.v.a. in the Arizona wing; the hydraulic turbines driving the larger units being of 115,000 h.p. Each of the 82,500 k.v.a. generators is $40 \mathrm{ft}$. in diameter, $32 \mathrm{ft}$. in height above groundlevel and weighs approximately 900 long tons. The stator frames are constructed entirely of steel plates and structural shapes electrically welded together. The rotors are $25 \mathrm{ft}$. in diameter, $8 \mathrm{ft}$. deep at the rim, and are carried in shafts 38 in. in diameter and 